\title{
Synergy Model of the Role of Local Government and Community in the Relocation of Slums in Jakarta Indonesia
}

\author{
Budi Supriyatno ${ }^{1}$ \\ ${ }^{1}$ Post-graduate Lecturer at Satyagama University, Jakarta, Indonesia \\ ${ }^{2}$ Director of Satyagama School of Information and Computer Management (STMIK), Jakarta, Indonesia \\ Correspondence: Budi Supriyatno. E-mail: drbudisupri@yahoo.com or budisupri@satyama.ac.id
}

Received: June 21, 2020

Accepted: July 14, 2020

Online Published: January 22, 2021

doi:10.5539/ass.v17n2p1

URL: https://doi.org/10.5539/ass.v17n2p1

\begin{abstract}
Abstret
The problem of slum areas along the river in Jakarta Indonesia does not only cover housing problems, but also social and economic problems for people living in slum areas. As city dwellers, they are entitled to a place to live and earn a living without breaking the rules. However, the DKI Jakarta Government has been taking issue with its citizens who have always refused to evict and relocate their citizens for a better life. In fact, the DKI Jakarta Government wants to arrange slum settlements along the river, which is done in stages with. Therefore, a synergy role model is needed to be built, among others, through direct public deliberations with its citizens which can be used as a good structuring pattern and can become a forum for communication between the Regional Government and the community. The steps that need to be taken are government efforts so that citizens can change their views to a more positive direction in assessing the policies of the DKI Jakarta Regional Government and how Regional Government policies can optimally implement the people's aspirations. To understand these problems, it is necessary to conduct research that examines the problems of slum settlements in Jakarta which are expected to produce solutions that can solve existing problems. This study aims to examine the perceptions, motivations and attitudes of the people of Jakarta towards local government policies. The goal is to be able to develop role models for the DKI Jakarta Regional Government and communities in slum settlements according to the aspirations and socio-economic conditions of the local community.
\end{abstract}

Keywords: local government, community, slum area, river bank

\section{Preliminary}

\subsection{Background}

The location of slums in Jakarta is in KampungPulo, the River Bank, South Jakarta. Especially on the banks of Ciliwung, KampungPulo, Jakarta, which are inhabited by 150 families or 750 people. ${ }^{[1]}$ Residents generally build residential houses in the river and river areas, even though they are already prohibited under the Regulation of the Minister of Public Works No. 63 / PRT / 1993, that the riverbanks are equal the river is a violation of the law. ${ }^{[2]}$ But residents still heed it, even residents who were on the banks of the river wanted a River Basin Regional Regulation to legalize their occupancy. Experts say:Lawrence Vale (2007),Due to increasing urbanization of the general populace, slums became common in the 18th to late 20th centuries in the United States and Europe ${ }^{[3]}$ While according to United Nations Habitat (2007) Slums are still predominantly found in urban regions of developing countries, but are also still found in developed economies. ${ }^{[4]}$ These two opinions can be concluded that slum settlements are a problem in big cities, both in developed and developing countries.

The problem of slum areas along the river, especially in KampungPulo, does not only cover housing problems, but also relates to the socio-economic problems of people living in slum settlements. As citizens of the city, they

\footnotetext{
${ }^{[1]}$ See Minister of Public Works of Republic Indonesia Regulation Number 63 / PRT / 1993 concerning River Border Lines, River Benefit Areas, River Control Areas, and Former Rivers.

${ }^{[2]}$ Data Source: Department of Population and Civil Registry, DKI Jakarta Province, 2018.

${ }^{[3]}$ Lawrence Vale (2007), From the Puritans to the Projects: Public Housing and Public Neighbors, Harvard University Press, ISBN 978-0674025752.

${ }^{[4]}$ United Nations Habitat (2007): Slums: Past, Present and Future
} 
are entitled to shelter and make a living without breaking the rules. This is what he asked the DKI Jakarta Provincial Government to become his obligation. Meanwhile, the DKI Provincial Government believes that its citizens always reject and reject efforts to control them. Meanwhile, residents argue that the DKI Jakarta Provincial Government only recommends evicting and has never been serious about a better life for its residents. Therefore, efforts need to be made so that citizens can change their views to a more positive direction in assessing the policies of the DKI Jakarta Regional Government and how these Regional Government policies can optimally implement the aspirations of the community. To understand these problems, it is necessary to conduct a study to examine the problems of slum settlements in Jakarta which are expected to produce the expected solutions to existing problems.

\subsection{Formulation of the Problem}

In order to realize the synergy of roles between the DKI Jakarta Government and the Community, the formulations of the problem are:

1. To what extent does the government treat the slum?

2. The extent to which citizens' perceptions and attitudes can change in policy assessments.

3. What is the policy of the DKI Jakarta Provincial Government in accommodating the aspirations of residents of slum areas.

In this regard, the handling of each typology of slum areas will of course be different because the aspirations of residents also depend on the socio-economic conditions of the residents of each location. Therefore, it must produce a model with a synergistic role in realizing a comprehensive slum area arrangement.

\subsection{Purpose and Objectives}

This research is intended to look at perceptions, motivations, attitudes of the community towards handling slum areas in Jakarta and related local government policies. The goal is that the DKI Jakarta Government can arrange slum areas based on the aspirations and socio-economic conditions of the local community.

\section{Methodology}

\subsection{Research Approach and Data Collection}

The approach that will be used in this study is a qualitative approach, namely by exploring problems from below and trying to find linkages between problems with one another to guide the course of the study and build new concepts.

Data collection was obtained through field observations, in-depth interviews and FGDs (Focus Group Discussion) while secondary data were obtained from the results of previous studies, statistical data from the Central Bureau of Statistics, government policies and regulations, articles, newspapers, the Internet and other documentation data related to slums in Jakarta.

Data analysis according to Miles and Hubermen (1994) is translated into four stages of activity, namely: the stages of identification, categories, interpretations, and conclusions. ${ }^{[5]}$ Starting from the background of a slum settlement in Jakarta.

This study took place in KampungPulo, KampungMelayu, Jatinegara, Jakarta East in Citizen Associations 02 and 03. The choice of location was determined based on the results of consultations from various parties including the Public Works Agency. The location of KampungPulo was chosen with the consideration that even this location had a refusal from the residents regarding the planned slum area for river normalization, the level of resistance was not so high.

\subsection{Conceptual Framework}

In accordance with Miles and Huberman's opinion, the conceptual framework needs to describe the main study dimensions, key factors or variables and the relationships between these dimensions. ${ }^{[\mathbf{6}]}$ Therefore, the conceptual framework of this research includes motivation, potential and social readiness of the community, as well as local government policies related to slum settlements. The DKI Jakarta Regional Government needs to synergize its role with the local community in an effort to organize slum area arrangements in conducive conditions, so that the continuity of the community's socio-economic activities can continue to run well and their needs remain met.

\footnotetext{
${ }^{[5]}$ Matthew B. Miles and A. Michael Huberman (1994) Qualitative Data Analysis:Aexponded Methods Sourcebook Edition 3. Publishied by SAGE. p.32

${ }^{[6]}$ Ibid, Matthew B. Miles andA. Michael Huberman (1994) p.33
} 
In brief, the conceptual framework can be seen in Figure 1.

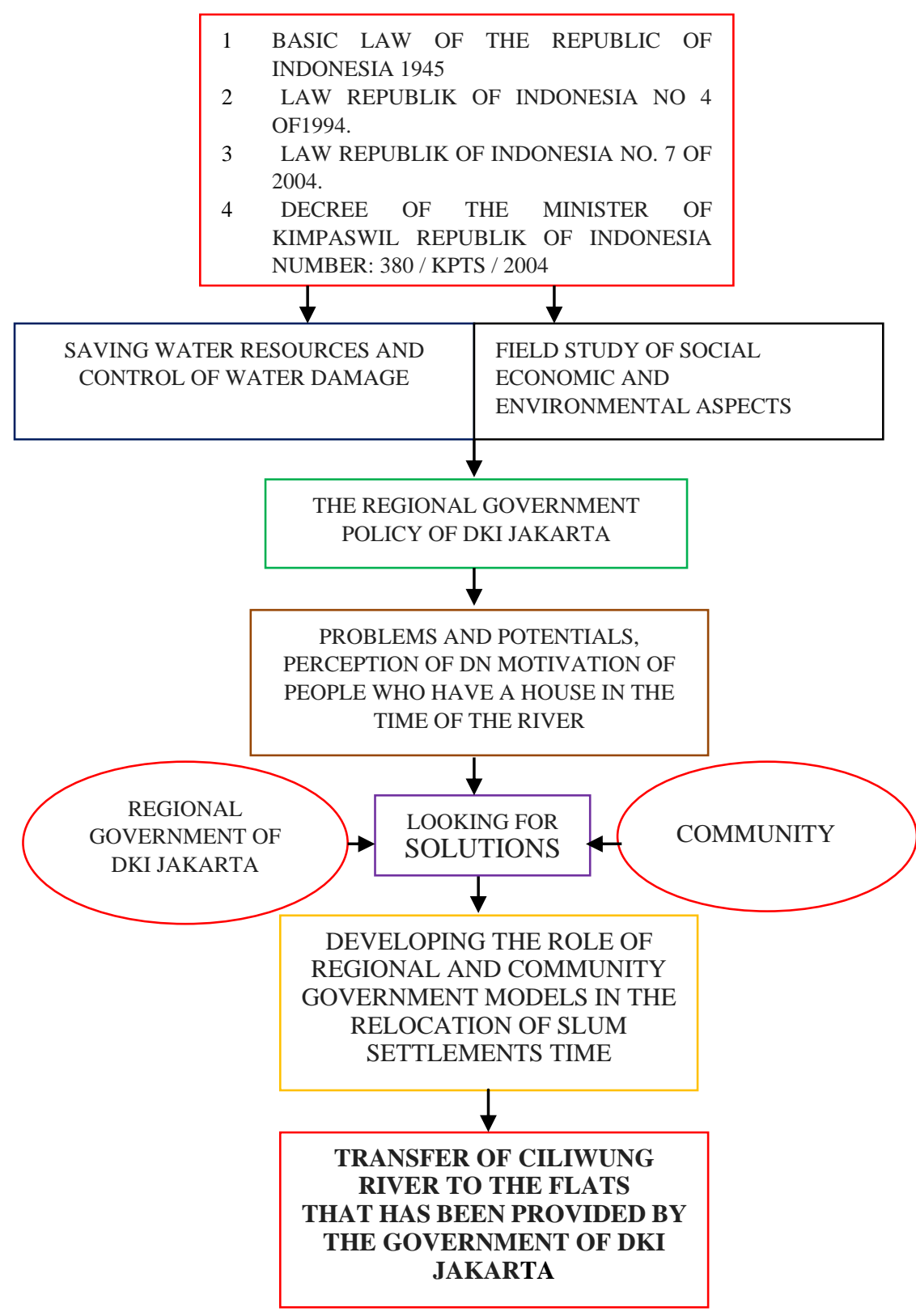

Figure 1. Development of the role of local government and community models in slum relocation by Budi Supriyatno

\section{Literature Review Data Research}

\subsection{Citizen Perspection, Participation, Rights and Obligations}

The emergence of perceptions, motivations, and attitudes between people in slum areas and the Provincial Government related to DKI Jakarta is the desire of the community to remain in slum areas on the one hand, while on the other hand the government tries to relocate the community. According to Bluth (1982: 37) because differences in cultural systems that each have. moral-evaluation categorization in the form of good and bad standards; and existential interpretations in the form of justification and legitimacy to act. ${ }^{[7]}$

For people who live in slum areas it is a good thing because they can build a life and run a business to support

${ }^{[7]}$ Bluth, B.J. 1982. Parson's General Theory of Action: A Summary of Nasic Theory. California, Granada Hills. P. 37. 
their family. Therefore, it is natural for residents to try and take various means to stay in the slum area. In fact, the DKI Jakarta Regional Government thinks that residents in slum areas are wrong and bad, because they damage the face of the city, cause many socio-economic and environmental problems, as well as various regulations. ${ }^{[8]}$

\subsection{Sinergy Definition}

The definition of synergy according to Budi Supriyatno (2012) is to build good cooperative relationships and harmonious partnerships with stakeholders such as the government and the community to produce useful and quality work. ${ }^{[9]}$ The goal of synergy is to influence the behavior of individuals as well as groups to interact, through dialogue with all groups, where perceptions, attitudes and opinions are important to a success.

Whereas according to, Henri Mazel, in 1896 applied the term "synergy" to social psychology by writing $\mathbf{L a}$ Synergiesociale, in which he argued that Darwinian theory failed to account for "social synergy" or "social love", a collective evolutionary drive. The highest civilizations were the work not only of the elite but of the masses too; those problems must be led, however, because the crowd, a feminine and unconscious force, cannot distinguish between good and evil. ${ }^{[10]}$ According to Lester Frank Ward in 1909, defined synergy as the universal construct of the principle of nature: I have characterized the social centrifugal struggle and centripetal social solidarity as. Either alone is the productive of evil consequences. Struggle is essentially destructive of the social order, while communism removes individual initiatives. The one to disorder, the other to degeneracy. What is not seen - the truth that is no - is that the wholesome, the constructive movement has the right ordered combination and interaction of these two principles. This is social synergy, which is a form of cosmic synergy, the universal constructive principle of nature. ${ }^{[11]}$

Synergy is complementary and complementary differences to achieve results greater than the number of parts per section. The concepts of synergy include the following: 1. Result-oriented and positive. 2. Diverse perspectives complement the new paradigm. 3. Mutual cooperation and goals together and an agreement. 4. Very Effective endeavored and is a Process. ${ }^{[12]}$

\subsection{Model Definition}

Model is a description that describes an object, system, or concept, which is often in the form of idealization. ${ }^{[13]}$ The form can be a physical model, image model, or mathematical formula. Concepts and theories: 1. Conceptual model, representation model for an idea or conceptual. 2. Data model, explanation of database structure. 3. Models (economics), theoretical simulations of an economic process. 4. Business model, a plan that explains business logic. ${ }^{[14]}$

According to Joyce "Each model guides us to help students achieve various objectives" ${ }^{[15]}$ which means that each model directs us in designing learning to help students achieve learning goals. According to Slavin the learning model is a reference to a learning approach including its purpose, syntax, environment, and management system. ${ }^{[16]}$

Hobley (1996) formulates the level and meaning of participation based on his experience implementing forestry development activities in India and Nepal, namely:

1. Manipulative Participation. The characteristics of this model are membership that is representative of a work commission, work organization or groups rather than individuals.

\footnotetext{
${ }^{[8]}$ Minister of Settlement and Regional Infrastructure Regulation of the Republic of Indonesia Number.380 KPTS / 2004.

${ }^{[9]}$ Budi Supriyatno (2012).Building Synergy between Regional Government and the Community for the Development of Blood.Briian Media Publisher.p.34

${ }^{[10]}$ Peter A. Corning, (2003). Nature's Magic: Synergy in Evolution and the Fate of Humankind, New York: Cambridge University PressISBN 0-521-82547-4; Peter A. Corning, Holistic Darwinism: Synergy, Cybernetics and the Bioeconomics of Evolution, Chicago: University of Chicago Press 2005 ISBN 0-226-11613-1

${ }^{[11]}$ Ward, Lester F. Glimpses of the Cosmos, volume VI (1897-1912) G. P. Putnam's Sons, 1918, p. 358

${ }^{[12]}$ Op.Cit. Budi Supriyatno (2012).p.34

${ }^{[13]}$ Op.cit. Budi Supriyatno (2012).p.35

${ }^{[14]}$ Budi Supriyatn.(2015). Slum Area Handling Model.Brilliant Media.p.14.

${ }^{[15]}$ Duhaime's Law Dictionary :Joyce Model of Joint Guardianship Definition: A British Columbia model of joint guardianship in respect to children as between separated parents.

${ }^{[16]}$ http://www.edpsycinteractive.org/topics/instruct/slavin_di.html.

${ }^{[17]}$ Mary Hobley 1996, Participatory Forestry The Prcess of Change in India and Nepal, Publised The Overseas Development Institute, Regent's College, Inner Circle, Regent's Parka Lodone NWI 4NS.p1-2.
} 
2. Passive Participation. People's participation is seen from what has been decided or what has happened, information comes from the administrator without wanting to hear the response from the public about the decision or information.

3. Participation by Consultation. People's participation by consulting or answering questions. People from outside define problems and the process of gathering information, and oversee analysis. The consultation process has no division in decision making, and people's views are not considered by outsiders ..

4. Participation for Material Insentive. People's participation through support in the form of resources, such as labor, food support, income or other material incentives. It is possible for farmers to provide land and labor, but they are not involved in the trial-trial and learning process. The disadvantage of this model is that if the incentives run out, the technology used in the program will not continue.

5. Functional Participation. People's participation is seen by external institutions as the ultimate goal of achieving project targets, especially reducing costs. The people may participate through group formation to determine the objectives related to the project. Such involvement may be quite interesting, because they are involved in decision making. But this happened after the decision had been made by people from outside the village. In short, villagers were co-opted to protect targets from people outside the village.

6. Interactive Participation. People's participation in joint analysis of the development of action planning and the establishment or emphasis of local institutions. Local participation is seen as a right and is not just a way to reach a project target. The process involves a multi-disciplinary methodology, there is a structured learning process. Decision making is local by groups and groups determine how the availability of resources is used, so that the group has the power to safeguard existing potential.

7. Self-Mobilization. People's participation through taking initiatives independently from outside institutions for system change. Communities develop relationships with external institutions for advice on the resources and techniques they need, but also keep an eye on how these resources are used.

\subsection{Participation}

The magnitude of the community's motivation to stay in the slums is inseparable, which he calls sociogenetic. Therefore the government's obligation to make arrangements and relocation so that the face of the city is more beautiful, organized, and the improvement of socio-economic and environmental problems. However, the relocation of slum dwellers on the edge of the river can not be done by means of violence which will only lead to social resistance and turmoil.

Participation comes from the English word "Participate" which means taking part. But in general community participation is often also interpreted as a contribution of energy, money, or goods in the framework of the success of a development program or project. In other words, participation means how much energy, funds, or goods can be provided as a contribution or community contribution to government projects.

Nancy Roberts in The American Review of Public Administration, Vol. 34, 4: pp. 315-353, said, Citizen participation decisions that affect their lives are imperative of contemporary society. ${ }^{[18]}$ For the first half of the 20th century, citizens are relied on public officials and decisions about public policy and its implementation. The latter part of the 20th century has shifted towards greater direct citizen involvement. This trend is more decentralized, interdependent, networked, linked to new information technologies, and challenged by "wicked problems." 1 19]

Rogers provides an understanding of participation as the level of involvement of members of the social system in the decision-making process for a plan.

While Davis said that participation is the mental and mental involvement of individuals in a group that encourages them to develop abilities according to the group's goals. Davis's frame of mind contains three main points. ${ }^{[21]}$ First, is mental and mind involvement. Second, the ability to act or work.Third, there is responsibility for group problems in achieving goals. ${ }^{[22]}$

[ 18 ] The American Review of Public Administration, vol. 34, 4: pp. 315-353. First Published Dec 1, 2000. https://doi.org/10.1177/0275074004269288.

${ }^{[19]}$ Ibid. Nancy Roberts/.p.315-353..

${ }^{[20]}$ Rogers, Everett M. Innovation Communication. (Yogyakarta: Sumbangsih, 1981), Hal. 63.

${ }^{[21]}$ Davis, Keith \& Newstrom, Jhon. 1996. Organizational Behavior : Human Behavior at Work. McGraw-Hill Series in Management. p.79.

${ }^{[22]}$ Ibid. Davis, Keith \& Newstrom, Jhon.p. 80 
Kohenargues that participation is involvement in the decision-making process, program implementation, utilization, and evaluation of results. ${ }^{[23]}$ The same opinion was expressed by $\boldsymbol{U}$ phof which states that participation is the involvement of the community in decision making, determining needs, withdrawing benefits, and evaluating programs. ${ }^{[24]}$

\subsection{The Role of Local Governments as Key Stakeholders}

In the process of structuring slum areas on the banks of the river in Jakarta residents must be able to participate, so efforts to multiply and develop the potential of citizens need to be done. Winarno (2004: 140) also said that a community facilitation process was needed to have the ability, namely: ${ }^{[25]}$

a. Analyze the situation in the environment.

b. Looking for problem solving based on the abilities of the limitations they have.

c. Develop their business, with all the capabilities and resources they have.

d. Develop a system to access the necessary resources.

Various empowerment efforts are also needed in accordance with the conditions of the local community, as stated by Jim Ife (19962) that empowerment is an increase in the capacity of the community to be able to manage themselves according to their knowledge and abilities. Thus, to relocate people in slum areas along the river should be based on the aspirations and social conditions of the community.

By using the reference to the good government reference, it is expected that in formulating forums to share the role of stakeholders, they can synergize with the four important elements of the government mentioned above.

\subsection{Research Data}

The data and information are categorized in problems and potential to be included in the model needs analysis. Each item or important parts of the data and information include the following:

\subsection{Environmental Aspects}

From a number of channels, there is one of the most crowded areas in Jakarta that is located in Citizens Association 02 and 03 KampungMelayu, Jatinegara, or known as the KampungPulo area. From the data of the DKI Jakarta Central Bureau of Statistics in 2013, the two Citizens Association (CA) have an area of approximately 3.7 ha and 3.36 ha. With that area, the Pillars of Citizens 02 and 03 are inhabited by approximately 4,356 people and 5,032 inhabitants. Every hectare of land in KampungPulo must be inhabited by approximately 1,500 people.

According to Robert, the two regions in KampungPulo, the Head of the DKI Jakarta Central Bureau of Statistics, will return to census at the end of this month (November 2017). The results of recommendations from the DKI Jakarta Central Bureau of Statistics will be submitted to the Regional Development Planning Agency. However, Robert said he did not know whether this area would be one of the areas that the DKI Provincial Government would organize (Interview Results November 17, 2017). Chairperson of the CA 03 Aga said the population in his area had experienced a slight shrinkage in the last two years. Of the 16 Neighborhood Associations there are only 12 Neighborhood Groups left. This is because the majority of its citizens are affected by the Ciliwung River normalization project. "There are only about 1,200 heads of households left," Aga said when interviewed by Researchers at his CA 03, KampungMelayu, Jatinegara, East Jakarta (Monday November 20, 2017).

When entering the KampungPulo area there is no road access for four-wheeled vehicles because of the narrow width of the road. The only access to four-wheeled vehicles is through the Ciliwung River normalization inspection road. Even though four-wheeled vehicles can only be parked on the edge, they cannot enter access to the village (Field Survey results on June 15, 2017, surveys are carried out up to 3 times).

The only access is using two-wheeled vehicles. The road is no less than one and a half meters wide. Almost no houses of citizens who have a home page. The majority of the houses are semi-permanent and have two floors. Two-wheeled vehicles cannot freely drive the vehicle. Drivers must share the place with vehicles parked on the

\footnotetext{
${ }^{[23]}$ Kohen, J. M. (1977). Rural Development Participation. (USA: Cornel University). p. 7.

${ }^{[24]}$ Norman Uphoff (1977). Rural Development Participation: Concept and Measures for Project Design. Implementation and Evaluation. Article (PDF Available) January 1977 with 3,879 Reads. https://www.researchgate.net/publication/37882394_ Rural_Development_Participation_Concept_and_Measures_for_Project_Design_Implementation_and_Evaluation ${ }^{[25]}$ See Winarno, S. 2004. Introduction to Scientific, Basic, Method and Engineering Research. Bandung: Tarsito. P.140.

${ }^{[26]}$ Lihat Jim Ife (1996) Community Development; Creating Community Alternatif-Vasion, Analysis and Practice. Longman. p. 182.
} 
road and children who use narrow alleys as a means of playing them. When walking around it is hardly found. Many environmental conditions with inadequate conditions. There are even neighborhood roads that do not have water channels, so when the rainy season arrives the threat of flooding often hits the area.

\subsection{Model in Determining Compensation}

For reference models in determining compensation, the residents stated the most were neighbors, reaching $44 \%$. For details in Table 1.

Table 1. Modeling in Determining Compensation

\begin{tabular}{cccc}
\hline NO & LIST OF INDEMNITY INSTITUTIONS & TOTAL & PERCENT (\%) \\
\hline 1 & PUBLIC FIGURE & 15 & $45 \%$ \\
2 & NEIGHBOR & 46 & $21 \%$ \\
3 & Citizens NEIGHBORS / LOCAL CITIZENS & 21 & $5 \%$ \\
4 & Village Officials & 5 & $4 \%$ \\
5 & DKI Government Apparatus & 4 & $9 \%$ \\
6 & NGO & 9 & $100 \%$ \\
\hline
\end{tabular}

Source: Processed data from Survey Results of Budi Supriyatno June 2018

\subsection{Institutional Aspects}

Organizational and institutional potential at the Research Site:

a. Number of influential figures.

b. Citizens Association level agency

c. Religious Organizations, and social organizations.

d. Political Institutions.

And the community's expectations for the Slum Area Planning Plan can be seen as Neighborhood Groups in the following Table 2.

Table 2. Expectations / Inputs to the Arrangement Plan

\begin{tabular}{cccc}
\hline NO & HOPE / COMMUNITY ENTRY & TOTAL & PERCENT (\%) \\
\hline 1 & Agree to Dismantling with Terms & 7 & $6 \%$ \\
2 & There is Deliberation with the Citizens & 23 & $20 \%$ \\
3 & There is certainty about implementation & 15 & $15 \%$ \\
4 & Initial Notification & 21 & $21 \%$ \\
5 & There is compensation & 5 & $5 \%$ \\
6 & Compensation Based on Deliberation & 6 & $6 \%$ \\
7 & Residents Do not be harmed & 9 & $8 \%$ \\
8 & The edge of Ciliwung River is cleaner & 2 & $6 \%$ \\
10 & Postponed First Implementation & 6 & $11 \%$ \\
& Disagree There Are Evictions & 12 & 106 \\
\hline
\end{tabular}

Source: Processed data from Survey Results of Budi Supriyatno June 2018

\subsection{Social Aspects}

The inhabitants of the river have long lived and evolved living entities. The most populous area in Jakarta, which is located in RukunWarga 02 and 03 KampungMelayu, Jatinegara or also known as the KampungPuloarea, has lived side by side like any other community. The social system they live in is also an increasingly entrenched social place.

An academic at Erlangga University, YayanSaktiSuryandaru said: "Moving them (slum residents) should not be interpreted as moving things or moving families. They are many and after "culture" internalized. So there is something that needs to be discussed openly, both with the citizens and from the government, so that there will be no violent clashes in the community, the community must not be harmed, even though the government is illegitimate on the land. There are no false attempts, even if the government has power. "[27]

${ }^{[27]}$ See Suryandaru in SukoWidodo, 2006. 


\subsection{Legal Aspects}

Experts from the explanation explained that the legality of regional law is indeed a form of "annexation" and cannot be justified. However, those at these locations have other views about ownership:

1. When the transfer they provide is clear and the compensation is higher.

2. Illegal status. The land status of residents around the banks of the Ciliwungriver in a limited area does not have a certificate $(100 \%)$.

3. The influence of External Institutions (NGOs), political party elites that will influence citizens has been anticipated by the DKI Jakarta Regional Government.

4. DKI Jakarta Regional Government Facilities: despite the complex solutions offered by resource persons that identified problems, the DKI Jakarta Government believes that efforts to organize slum areas along the river need to be carried out (Interview with officials who do not want to be named on 22 November 2017).

\subsection{Some Perceptions of Community Leaders}

The results of the research and information on the results of the FGD in this study, showed a soft attitude from the residents towards the arrangement plan, even though in substance the demands were relatively the same. This attitude arose when the FGD was held with community leaders and community representatives who outlined the following:

1. Residents are essentially aware that they occupy land that is not theirs. However, the land was empty and for a long time it seemed like no one had / took care of it, so what would be wrong if the residents occupied it just to take shelter and connect their lives.

2. Therefore, actually the citizens are ready and willing to participate in the environmental arrangement provided that the government immediately realizes it, not only promises or plans like this.

3. The community is willing if at any time they have to leave the place as long as they are treated properly as people who have lost their homes and livelihoods.

4. For vacant land, residents request that they be built according to the government's plans (inspection roads, parks, social facilities, public facilities, etc.) so that the migrants will no longer occupy them.

5. In the structuring plan and including any development programs that will be implemented for the residents, the Regional Government of DKI Jakarta is asked to act as a father to children.

\section{Discussion Result}

\subsection{Understanding the Nature of the Model}

Before developing a model that is synergized with the role of the DKI Jakarta Regional Government and the community in structuring slum areas, it must first apply the nature of a model. The actual model is a representation of the system. The system is a dynamic structure, while the structure is a thought made in such a way as to be made by the basic elements needed where each element has a dependence on one other functionality in achieving a common goal.

Therefore, in preparing a model it is necessary to pay attention to the characteristics or elements of the system. Characteristics and elements that must be fulfilled for a model, as a representation of the system: ${ }^{\text {[8] }}$

1. Consisting of components in it as a subsystem, where each component has a network of relationships with each other.

2. Is a unity in the system.

3. Mutual integration in achieving common goals.

4. The system is a dynamic structure.

5. Mutual interaction between components in the system.

6. The existence of functional interdependence between components and subsystems.

7. Having input and output, where input moves the system which then produces output.

8. System and components in the system are able to adapt to the environment.

\footnotetext{
${ }^{[28]}$ Op.cit.Budi Supriyatn.(2015).p.15.
} 


\subsection{Analyze the Stages of Field Studies for Problem Identification and Potential}

1. Preliminary Study

a. Past Program Evaluation

Evaluate the programs that have been implemented in various aspects:

1) The extent of past related programs (structuring the slums of the Ciliwung riverbanks that have been carried out the previous year by the Public Works Agency has fulfilled what is expected and planned by the DKI Government.

2) How far the activities of structuring the residents of the slum area have fulfilled the wishes and needs of the local community.

b. Evaluation of the Negative Social Impact that arises

Besides evaluating the value of benefits, an evaluation was also conducted in the event of a negative social impact due to the implementation of the previous 2014 structuring program.

2. DoingSocial Mapping

a. Carry out field studies (Filed Research of Social Mapping)

1) Carrying out data collection using the Neighborhood Participatory Action Research (PAR) approach through the Rapid Appraisal Method, FGD and discussion in the community.

2) Identify the boundaries and characteristics of the mapping area, literature review, then determine the issues in the community that have potential and have an interest in terms of interests in relation to the arrangement of the Ciliwung River Slums.

3) Conduct institutional identification at the micro (community) and macro level (level above the community) What institutions are there, social, general religion, Neighborhood Association (NA)/ CA, Youth Organization and so on, private sector. It needs to be described how the pattern of relationships / interactions between these organizations.

4) Identifying potential that exists within the community and stakeholders, both actual and symbolic potential.

b. Enter the Social Mapping Results into the Model.

The results of this study will be a consideration in the model and integration of the programs to be offered, both those that are potential (actual and symbolic) and constraints.

1) Potential Considerations. For example at the socialization program, the importance of waste management through environmentally friendly recycling methods presents female leaders, mayors and groups of mothers CA Family Welfare Program 07 leaders of women and mothers The Family Welfare Program is all committed to waste management for Neighborhood Unit for cleanliness and sustainable environmental health.

2) Obstacle Considerations. In reading together, balancing the constraints, for example, is the consideration of people's perceptions that tend to be negative towards the structuring program. The attitude of the residents was influenced by the implementation of slum area arrangement that had been carried out the previous year which had run smoothly. In addition, residents also considered that since then the provincial government often prepared a structuring plan, but it had never been realized. Residents were upset because there was uncertainty from the government, even the land in the slum area that had been released was left empty and not immediately built. Therefore, the prepared model must be able to be implemented in the following year and vacant land that has been freed must be built immediately.

3. Macro Dimension (Governor of DKI Jakarta, Mayor, Department of Parks and Empowerment of City Government, Office of Settlements and Public Works Office, Regional Development Planning Agency and sub-district):

a. In the context of the arrangement of the Slum Jakarta Area Alternative is the Construction of Flat Housing, the Regional Government of DKI Jakarta will provide land owned by the Regional Government as a candidate location for the flats.

b. The Governor of DKI Jakarta also led the implementation of structural housing that has been mandated by the people by deciding on the regional expenditure budget funds including the amount as 
operational funds for development at the community level by means of "block grants" and authorizing the Neighborhood Unit to independently manage operational funds for the development of local continuity.

c. The role of the department within the DKI Jakarta Regional Government: to continue to carry out physical development, but at the smallest level of community NA, agency must submit fully the tasks and arrangements and development to the NA. The office needs to provide information, education and facilities to the Neighborhood Unit in carrying out their respective sector development.

d. The role of the sub-district should not be to determine or select proposals from the Neighborhood Association because it will prolong the procedure of bureaucracy and will cause people's aspirations to disappear, Head of The Sub-District

e. should continue to play a role in the routine government and in development that are sectoral in their neighboring communities, conduct monitoring, control and reporting.

\subsection{Model Analysis Matrix}

The next step after understanding the model is the stage of idealizing the model that is needed through the analysis matrix of the needs of the same model of neighboring groups seen in Table 3 .

Table 3. Matrix of Analysis of Model Needs Synergizing the Role of DKI Jakarta Regional Government and Communities in Structuring the Slums of KampungPulo in the Ciliwung River Side

\begin{tabular}{|c|c|c|c|c|c|}
\hline No & $\begin{array}{l}\text { Identification of Problems \& } \\
\text { Potentials }\end{array}$ & $\begin{array}{c}\text { Alternative } \\
\text { Management } \\
\text { Solutions }\end{array}$ & $\begin{array}{l}\text { The Role of the } \\
\text { Community }\end{array}$ & $\begin{array}{l}\text { Role of DKI } \\
\text { Jakarta } \\
\text { Provincial } \\
\text { Government }\end{array}$ & $\begin{array}{c}\text { Identification Sub } \\
\text { Systems of } \\
\text { Model Elements }\end{array}$ \\
\hline 1 & $\begin{array}{l}\text { PERCEPTION OF } \\
\text { COMMUNITY STORIES } \\
\text { a. Less effective } \\
\text { socialization plan. } \\
\text { b. Understanding Less } \\
\text { People } \\
\text { c. Citizen aspirations agreed } \\
\text { with the eviction of } 35 \% \\
\text { and disagreed } 65 \%\end{array}$ & $\begin{array}{l}\text { a. Socialization } \\
\text { should be directed } \\
\text { so that citizens } \\
\text { understand the } \\
\text { plan of slum area } \\
\text { of goals, benefits, } \\
\text { compensation } \\
\text { b. can } \\
\text { accommodate the } \\
\text { aspirations of } \\
\text { citizens through } \\
\text { group discussions } \\
\text { and building } \\
\text { agreements. } \\
\text { c. Utilize the role } \\
\text { of social } \\
\text { institutions at the } \\
\text { community level } \\
\text { that are still } \\
\text { functioning well } \\
\text { as communication } \\
\text { channels in the } \\
\text { arrangement plan. }\end{array}$ & $\begin{array}{l}\text { a. Present in the } \\
\text { socialization with } \\
\text { neighborhood (CA), } \\
\text { neighborhood (NA) and } \\
\text { community leaders. } \\
\text { b. Take an active role in } \\
\text { communicating needs } \\
\text { and wants and } \\
\text { aspirations. } \\
\text { c. Understanding } \\
\text { legislation. }\end{array}$ & $\begin{array}{l}\text { a. Facilitate the } \\
\text { implementation } \\
\text { of socialization. } \\
\text { b. Describe the } \\
\text { relevant } \\
\text { programs and } \\
\text { policies. } \\
\text { c. Each of them } \\
\text { synergizes the } \\
\text { role of: } \\
\text { 1) The role of } \\
\text { City } \\
\text { Government. } \\
\text { 2) The role of the } \\
\text { Public Works } \\
\text { Department. } \\
\text { 3) The Role of } \\
\text { Regional } \\
\text { Development } \\
\text { Planning Board. } \\
\text { 4) The role of the } \\
\text { Housing Service. } \\
\text { 5) The Role of } \\
\text { the Sanitation } \\
\text { Office. } \\
\text { 6) The Role of } \\
\text { the Civil Service } \\
\text { Police Unit. }\end{array}$ & $\begin{array}{l}\text { a. Establish } \\
\text { effective systems } \\
\text { and socialization } \\
\text { mechanisms. } \\
\text { b. Establish } \\
\text { stakeholder } \\
\text { coordination } \\
\text { forums. }\end{array}$ \\
\hline
\end{tabular}


2 SOCIAL ECONOMY ASPECTS:

a. Residents requested appropriate compensation in the form of money or relocation $(69.51 \%)$

b. Land and buildings are unauthorized possessions of aseet without title certificates.

\section{INSTITUTIONAL}

\section{ASPECT:}

a. Already formed the CA, NA.

b. Already formed informal institutions such as collection of mothers, and group religion

\section{LEGAL ASPECT}

a. Residents are aware of the utilization and status of land ownership by law illegally.

b. Government has the task a. Determination of the value of land and compensation shall be made by deliberation after the community understands the plan and utilization.

b. Relocation is done on better environmental conditions.

c. Integration of various agencies and agencies and regional and central stakeholders.

d. Requires funding support and legal provisions that can be sheltered.

\section{a. Utilizing} existing institutions as communication channels between government and society.

b. The principle of law enforcement is done by social approach in order to fluctuate.

c. Building a thorough understanding of applicable legislation.

d. Beginning with social mapping, aspirations and community views.

a. The principle of law enforcement is done by social approach in order to fluctuate.
a. Active in community
a. Facilitate consultation on the use of deliberations to relocation for a better life. actively convey aspirations.

b. Take an active role in

b. Relocation expressing opinions

co-relocation programs post-relocation coaching.

a. Residents are active in group meetings.

b. Community active community leaders participated in the socialization and subsequent training to assist the residents.

\section{a. Improve group understanding and capability. \\ b. Conduct training.}

c. Allocate funds for group empowerment. a. Strengthen the stakeholder forum in program integration and funding.

b. Strengthening program and funding integrity.

c. Strengthening special funding during post-relocation mentoring relocation

\section{a. Establish systems and mechanisms for community and institutional synergy and stakeholders. \\ b. Stakeholder communication forums for integrated activities and funding.}

\begin{tabular}{lll}
$\begin{array}{l}\text { a. Active in groups to } \\
\text { improve understanding } \\
\text { of the applicable }\end{array}$ & $\begin{array}{l}\text { a. Active } \\
\text { through legal } \\
\text { guidance and }\end{array}$ & $\begin{array}{l}\text { a. strategic } \\
\text { measures to build } \\
\text { a non- }\end{array}$ \\
$\begin{array}{l}\text { counseling that } \\
\text { b. Officials and }\end{array}$ & $\begin{array}{l}\text { is offset by the } \\
\text { socio-economic } \\
\text { relationship }\end{array}$ \\
\hline
\end{tabular}


of managing the city properly and correctly in accordance with applicable laws and regulations.
ASPECTENVIRONMENT
a. The condition and quality of the shelter environment is inadequate.
b. Clean water facilities and toilets are inadequate.
c. Flood and puddle threats.
d. Environmental sanitation conditions: 28 households usually defecate in rivers /
e. Permanent settlement:
3,366 houses. Semi permanent: $2927.54 .35 \%$
occupancy density and existing buildings occupied by 5 peple more each.
b. Building a
thorough
understanding of
applicable
legislation.
c. Beginning with
social mapping,
aspirations and
community views

community institutions
to assist their citizens in
consultation with the
government of DKI
Jakarta.

Through a participatory approach to improving the condition and quality of the environment and occupancy with the awareness of citizens and understanding of the relocation program for a better, healthier,

Actively participate actively in groups and activities in improving the quality of the environment.

Establish a group of people concerned about safety

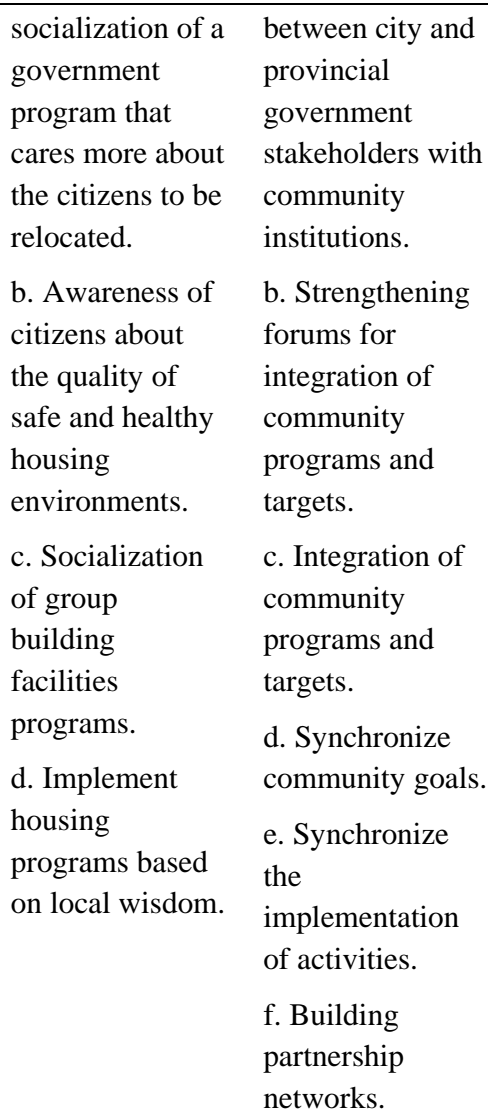

Implementing
local
wisdom-based
stimulation
program.
environmental health and

\section{Chart Analysis Analyzes Model Building}

After making a matrix analyzing the model needs, the next step is to build the model configuration. The steps at this stage include:

1. Strengthening the elements of the model resulting from identification so that they are truly representative of the system. This is done by juxtaposing / matching the model elements with the cirri system or elements of the system that have substance similarities, the identification results are correct. Both are given the same number and are bold, the module element on the right, and the system elements on the left.

2. Strengthening the substance aspects of the model elements as part of the slum area arrangement model. This is done by describing the system elements (theoretical discourse and conceptual dimensions) and 
describes the model's ability (results of empirical studies and practice studies). The results of the translation are written under each element. All of them appear in the section below.

\section{Stage Model Implementation Analysis}

1. Social Preparation. After field identification is complete, the working mechanism of the model of the structuring program can be arranged. Before the final design of the model needs to be discussed and agreed upon with various parties:

a. Meeting between stakeholders (City Government, Provincial Service and Community / Community Leaders, Religious leaders, elders of citizens and so on to formulate and agree on a structuring plan (by presenting the results of research and identification of the field).

b. Agree on the vision or future of slum residents among stakeholders and formulate strategies that will be taken in implementing the implementation of the role in a participatory manner.

c. Agree on definitions of development concepts used in the model.

d. Agree on the basic principles that will be used as a benchmark for development activities.

e. Regional political statements (especially the Regional People's Representative Council).

f. After the concept of the model is discussed corrected and principally accepted by stakeholders, a final model is prepared.

g. The model was then socialized to the community (especially in the pilot project area and research was conducted for government facilitators / NGO assistants in the neighborhood unit of all levels of regional government officials and universities.

h. After the model can be tried for one year. As long as it is monitored by the university parties scientifically (objectively and systematically) then evaluated.

i. Based on the evaluation of the DKI Jakarta Regional Government and the Regional People's Representative Council, a decision was made to expand the implementation of the model in other slum communities in the slums of Jakarta. The focus of attention on the model that will be prepared is mainly for the slum area community because the city is very different from the village community. After that a new model will be developed for the village community (upstream area).

2. Model Implementation Mechanism. As described above, the model includes the micro dimension (level of neighborhood / neighborhood and macro dimensions (sub-district / city / province level).

a. Approach to Micro Dimensions (Community Level).

1) To take an approach it is necessary to strengthen institutional capacity. The most obvious way is to give trust, responsibility and authority to the community in accessing and managing development funds.

2) For this reason, the Regional Government needs to explore to give authority to the Neighborhood Unit to receive and manage operational funds directly from the Regional Budget expenditure budget in the form of block grants which can be integrated with community self-help funds.

3) The funds can be obtained through the Village Officials by submitting a proposal (project proposal) which is prepared jointly by the residents.

4) The criteria for the amount of funding for each community unit / Neighborhood Unit is the importance of the proposed development project, but also the amount of assistance that can be provided by all citizens (for example in the form of funds, natural contributions, and voluntary labor, etc.).

\section{Implementation of the Model through Preparation}

Before being implemented, the design of the model needs to be discussed and agreed upon by the parties, so that the following steps need to be carried out:

a. Meeting between stakeholders (Regional People's Legislative Assembly, DKI Jakarta Government, community leaders, traditional and religious leaders, etc.) to socialize the model while formulating and agreeing on slum area management issues.

b. Agree on the vision and mission with slum communities. Among stakeholders and formulate strategies to 
be taken.

c. Agree on the development concept that will be used.

d. Agree on the basic principles that will be used as a benchmark for development activities.

e. Statement about the "political will" of the region, especially by the Regional People's Representative Council.

\section{Conclusion and Recommendation}

\subsection{Conclusion}

Previous research entitled Sustainable Development of Urban Slum Areas In Northwestern Spain at: http://dx.doi.org/10.1108/MEQ-06-2014-0095. Written by: Carmen Gago-Cortés Economic Analysis and Business Administration, University of A Coruna, A Spain, and Isabel Novo-Corti Economic Development and Social Sustainability Research Group, University Institute of Maritime Studies.

The similarities both discuss about slum areas, while the difference is, this article emphasizes the implementation of the sustainable development of urban slums by the Spanish Government. Meanwhile, my paper discusses the Synergy Model of the Role of Local Government and Society in Public Relocation in Jakarta, Indonesia. So that the emphasis is different on the implementation of development and the synergy model of the roles of local government and society.

From the description above can be concluded as follows:

1. Slum arrangement in Jakarta must be carried out in stages and focus on certain areas, but provided that a definite legal umbrella is provided.

2. The synergy role model that is built, among others, through direct public deliberations (deliberations on the mention of citizens) can be used as an arrangement pattern in several places because it can become a communication forum for Regional Governments throughout Indonesia and the Community.

3. The use of local leaders to participate in the arrangement of regional regulations is very important in the model, however, it must also be addressed carefully so that this figure can act as a fair mediator to become a channel of communication between the Regional Government and the community. in a synergistic role.

4. The need to increase and expand coordination forums between government agencies, both central and regional, in meeting the needs of citizens in various roles.

5. Perceptions received by residents of the slum management program are generally positive in that they are willing to support the program, but with the condition that the DKI Jakarta Provincial Government must have certainty about the implementation of the program so that residents are not anxious.

\subsection{Recommendation}

1. The model of role synergy in the management of slum areas by giving the role of the community plays a very important role considering that they are one of the subjects not the object of the slum arrangement plan.

2. The basic capital of solving this problem is cooperation and mutual understanding between the DKI Jakarta regional government and the residents.

3. Basically the statement of residents of slum dwellers can work together with the Regional Government, but this is not enough, strong commitment is still needed from both residents and the local government to implement slum area management.

4. It is necessary to explore the possibility of cooperation with the private sector in the framework of structuring the riverbank area. The form of participation offered must guarantee the symbiosis of mutualism which leads to an increase in the welfare of the community in a wide range of neighborhoods.

5. The appropriate community approach strategy is through institutions in the community where the role of the government can provide an optimal dissemination of slum area planning programs. This community group is basically representative to be involved in the dissemination of programs and legislation.

6. Then it is important for stakeholders, especially from government elements that represent the sector, to immediately show their respective budgetary readiness and set out in the program integration matrix.

\section{References}

Abel, R. D., \& Stephan, M. (2000). The limits of civic environmentalism. American Behavioral Scientist, 44(4), 
614-628.

Aleshire, R. A. (1972). Power to the people: As assessment of the community action and model cities experience. Public Administration Review, 32, 428-442.

Almond, G. A., \& Verba, S. (1989). The civic culture (3rd ed.). Newbury Park, CA: Sage.

Anonym. (n. d.). Kampung Improvement Program. Retrieved from http://www.mukimints.com

Anonym. (n. d.). The Stren Kali advocacy. Retrieved from http://www.upc.com

Anonym. (n. d.). Type of Slum Settlement. Retrieved from http://www.jakarta.go.id

Arnstein, S. R. (1972). Maximum feasible manipulation. Public Administration Review, 32, 377-389.

Aron, J. B. (1979). Citizen Participation at government expense.Public Administration Review, 39(5), 477-485.

Austin, D. M. (1972). Resident Participation: Political mobilization or organizational co-optation? Public Administration Review, 32, 409-420.

Bacharach, S. G., \& Lawler, E. J. (1981). Bargaining, power, tactics, and outcomes. San Francisco: Jossey-Bass.

Bachrach, P., \& Baratz, M. S. (1962). Two faces of power. American Political Science Review, 56, 947-952.

Barber, B. (1984). Strong democracy: Participation politics for a new age. Berkeley and Los Angeles: University of California Press.

Berry, J. M. (1981). Beyond citizen Participation: Effective advocacy before administrative agencies. Journal of Applied Behavioral Science, 17(4), 463-477.

Bluth, B. J. (1982). Parson's General Theory of Action: A Summary of Nasic Theory. California, Granada Hills.

Bohman, J., \& Rehg, W. (1997). Deliberative democracy: Essays on reason and politics. Cambridge, MA: MIT Press. Participation and the economic oppoRukunTetanggaunity act. Public Administration Review, 32, 444-456.

Box, R. C. (1998). Citizen governance: Leading American communities into the 21st century. Thousand Oaks, CA: Sage.

Brudney, J. L., \& England, R. E. (1983). Toward a definition of the coproduction concept. Public Administration Review, 43(1), 59-65.

Bryson, J. M., \& Anderson, S. R. (2000). Applying large-group interaction methods in the planning and implementation of major change effoRukunTetanggas. Public Administration Review, 60(2), 143-153.

Buck, J. V., \& Stone, B. S. (1981). Citizen involvement in planning: Myth and reality. Journal of Applied Behavioral Science, 17(4), 550-565.

Bunker, B. B., \& Alban, B. T. (1997). Large group interventions: Engaging the whole system for rapid change. San Francisco: Jossey-Bass.

Burke, E. M. (1968). Citizen Participation strategies. Journal of the American Institute of Planners, 34, $287-294$.

Cole, R. L., \& Caputo, D. A. (1984). The public hearing as effective citizen Participation mechanism: A case study of the General Revenue Sharing Program. American Political Science Review, 78(2), 404-416.

Cooper, T. L. (1984, March). Citizenship and professionalism in public administration [Special issue]. Public Administration Review, 143-149.

Corning, P. A. (2003). Nature's Magic: Synergy in Evolution and the Fate of Humankind. New York: Cambridge University Press.

Corning, P. A. (2005). Holistic Darwinism: Synergy, Cybernetics and the Bioeconomics of Evolution. Chicago: University of Chicago Press.

Crompton, J. L. (1983). Recreation vouchers: A case study in administrative innovation and citizen Participation. Public Administration Review, 43, 537-546.

Crosby, N., Kelly, J. M., \& Schaefer, P. (1986). Citizens panels: A new approach to citizen paRukun Tetanggaicipation. Public Administration Review, 46(2), 170-178.

Cunningham, J. V. (1972). Citizen Participatioin public affairs. Public Administration Review, 32, $589-602$.

Cupps, D. S. (1977). Emerging problems of citizen Participation. Public Administration Review, 37(5), $478-487$.

Dahl, R. A. (1971). Polyarchy: Participation and opposition. New Haven, CT: Yale University. 
Darwinism: Synergy, Cybernetics and the Bioeconomics of Evolution. (2005). Chicago: University of Chicago Press.

Davis, K., \& Newstrom, J. (1996). Organizational Behavior: Human Behavior at Work. McGraw-Hill Series in Management, 79.

Day, D. (1997). Citizen Participation the planning process: An essentially contested concept? Journal of Planning Literature, 11(3), 412-434.

Decree of the Minister of Settlement and Regional Infrastructure (Number 380).

Desai, U. (1989). Public Participation in environmental policy implementation: Case of the Surface Mining Control and Reclamation Act. The American Review of Public Administration, 19(1), 49-66.

DeSario, J., \& Langton, S. (1984). Citizen Participation and technology. Policy Studies Review, 3(2), 223-233.

Duhaime's Law Dictionary: Joyce Model of Joint Guardianship Definition: A British Columbia model of joint guardianship in respect to children as between separated parents.

Hobley, M. (1996). Participatory Forestry ThePrcess of Change in India and Nepal. Publised The Overseas Development Institute, Regent's College, Inner Circle, Regent's Parka Lodone NWI 4NS.

Ife, J. (1996). Community Development; Creating Community Alternative-Vasion, Analysis and Practice. Longman.

Indriantoro, N., \& Supomo, B. (2002). Business Research Methods for Accounting and Management. Yogyaka Rukun Tetanggaa: PT. BPFE.

Kohen, J. M. (1977). Rural Development Participation (USA: Cornel University).

Miles, M. B., \& Huberman, A. M. (1994). Qualitative Data Analysis: An expeded Methods (Sourcebook Edition 3). Publishied by SAGE.

Minister of Public Works Regulation Number 63 / PRT/1993 concerning River Border Line, River Benefit Area, River Mastery Area, and Former River.

Minister of Settlement and Regional Infrastructure Regulation Number. 380 KPTS / 2004.

Nancy RobertsdalamNancy Roberts Naval Postgraduate SchoolNorman Uphoff. (1977). Rural Development Participation: Concept and Measures for Project Design. Implementation and Evaluation. Retrieved from https://www.researchgate.net/publication/37882394_Rural_

Development_Participation_Concept_andMeasures_for_Project_Design_Implementation_and_Evaluation

Roberts, N. (2004). Public Deliberation in an Age of Direct Citizen Participation. The American Review of Public Administration, 34(4), 315-353. https://doi.org/10.1177/0275074004269288

Schumpeter, J. (1943). Capitalism, socialism and democracy. London: Allen \&Unwin.

Supriyatno, B. (2012). Building Synergy between Regional Government and the Community for the development of Blood. Media Brilliant.

Supriyatno, B. (2015). Slum Area Handling Model. Brilliant Media.

United Nations Habitat. (2007). Slums: Past, Present and Future.

Vale, L. (2007). From the Puritans to the Projects: Public Housing and Public Neighbors. Harvard University Press.

Ward, L. F. (1918). Glimpses of the Cosmos. Volume VI (1897-1912) G. P. Putnam's Sons, p. 358.

\section{Copyrights}

Copyright for this article is retained by the author(s), with first publication rights granted to the journal.

This is an open-access article distributed under the terms and conditions of the Creative Commons Attribution license (http://creativecommons.org/licenses/by/4.0/). 